\title{
KREATIVITAS KEPEMIMPINAN \\ KEPALA RAUDHATUL ATHFAL AS-SALAM KOTA AMBON DALAM MENINGKATKAN PENDIDIKAN AGAMA
}

\author{
The Head's Leadership Creativity of \\ Raudhatul Athfal As-Salam in Ambon \\ in Improving Religious Education
}

\author{
Baso Marannu \\ Balai Penelitian dan Pengembangan Agama Makassar \\ Jl. A.P. Pettarani No. 72 Makassar \\ Email: athobasomarannu70@gmail.com
}

Naskah diterima tanggal 3 Januari 2013. Naskah direvisi tanggal 25 Januari 2013. Naskah disetujui tanggal 11 Februari 2013

\begin{abstract}
Abstrak
Pendidikan Anak Usia Dini merupakan salah satu bentuk penyelenggaraan pendidikan yang menitikberatkan pada peletakan dasar ke arah pertumbuhan dan perkembangan fisik, kecerdasan, sosio emosional, bahasa dan komunikasi, sesuai dengan keunikan dan tahap-tahap perkembangan yang dilalui oleh anak usia dini. Tujuan dari penelitian ini menganalisa Pelaksanaan Standar Pendidikan Anak Usia Dini sesuai Permendiknas Nomor 58 Tahun 2009 dikaitkan dengan pengembangan model Kepemimpinan RA. serta pengelolaan RA As-Salam dikaitkan dengan kreatifitas Kepemimpinan. Penelitian Kualitatif ini menyimpulkan Gaya kepemimpinan Kepala RA As-Salam lebih bersifat situasional dengan memadukan beberapa sekolah sukses, khusus kreatifitas kepemimpinan sangat mempengaruhi pengembangan kurikulum, kedisiplinan, pengelolaan informasi, kegiatan ekstra kurikulur hingga sistem evaluasi, pada akhirnya sebuah RA yang dikoordinasikan oleh Kemenag juga dapat memperlihatkan kualitas pengelolaan dan pelayanan pendidikan secara baik.
\end{abstract}

Kata kunci: kepemimpinan, kreativitas, raudatul atfal

\begin{abstract}
Early childhood education is one of the education implementations focusing on putting foundation toward physical growth and development, intelligence, socio-emotional, language and communication which were according to uniqueness and development stages experienced by early childhood. The research aimed at analyzing the implementation of Early Childhood Education Standard based on the regulation of National Education Ministry No. 58 of 2009 which was associated with the leadership model development of Raudhatul Athfal As-Salam and the its management was associated with the leadership creativity. The qualitative research concludes that the head's leadership style of Raudhatul Athfal As-Salam is situational by combining several successful schools. Particularly, the leadership creativity influences greatly the development of curriculum, discipline, information management, extracurricular activities, and the evaluation system. Finally, Raudhatul Athfal As-Salam coordinated with by the Ministry of Religion can show well management quality and education services.
\end{abstract}

Keywords: leadership, creativity, raudhatul athfal

\section{PENDAHULUAN}

$\mathrm{F}$ enomena tentang kepemimpinan tentu menarikuntuk diteliti hingga saatini. Meskipun ada perhatian terhadap kepemimpinan dan nilai pentingnya, kepemimpinan tetaplah sebuah "black box" atau konsep yang tidak bisa dijelaskan, yang dikenal memiliki pengaruh terhadap kinerja manusia, dan selalu didefenisikan dengan berbeda, satu-satunya yang lazim adalah peran yang memengaruhi kepemimpinan (Luthans, 2006: 638)

Pandangan kalangan akademisi, pakar, peneliti dan pengamat melihat bahwa kepemimpinan dipandang sebagai misteri dan mencari penjelasan 
atas esensi sesungguhnya dari kepemimpinan (Danim, 2010: 7) Kepemimpinan bukanlah statis; kepemimpinan bersifat aktif dan terus menerus berubah secara konstan (White,1997: 26)

Penulis beranggapan bahwa saat ini kepemimpinan masih menarik untuk diteliti, karena dalam sebuah organisasi cenderung dinamis mengikuti perkembangan sesuai dengan tujuan organisasi. Frances Hesselbein mengatakan bahwa kepemimpinan berhubungan dengan "Bagaimana menjadi" (how to be) yakni bagaimana mengembangkan kualitas, sifat, pikiran (mind-set), nilai, prinsip dan keberanian, bukan "bagaimana melakukannya" yang hanya larut dalam perubahanperubahan ke depan (Hesselbein, 2007: 6)

Pendidikan Anak Usia Dini (PAUD) merupakan salah satu bentuk penyelenggaraan pendidikan yang menitikberatkan pada peletakan dasar ke arah pertumbuhan dan perkembangan fisik (koordinasi motorik halus dan kasar), kecerdasan (daya pikir, daya cipta, kecerdasan emosi, kecerdasan spiritual), sosio emosional (sikap dan perilaku serta agama) bahasa dan komunikasi, sesuai dengan keunikan dan tahap-tahap perkembangan yang dilalui oleh anak usia dini.

Selama ini beberapa penulis berbicara tentang kepemimpinan selalu dihubungkan dengan perusahaan besar yang mengarah pada keuntungan finansial. Pertanyaan sederhana yang penulis ingin ungkapkan bahwa bagaimana dengan kepemimpinan pada lembaga pendidikan atau lebih sederhana lagi kepemimpinan pada Sekolah Raudhatul Atfhal (RA) dibawah koordinasi Kementerian Agama, yang terkadang masih dilihat sebelah mata jika dibandingkan dengan TamanKanak-Kanak yang pengelolaannya di bawah Dinas Pendidikan dan Kebudayaan

Menurut Penulis, ini menarik, karena seorang Kepala RA memimpin dan mengarahkan guru RA yang tidak terlalu banyak rara-rata guru RA antara lima san sembilan guru tiap RA tergantung besar kecilnya RA tersebut. Guru-guru tersebut memberikan pelajaran bagi anak-anak yang berumur sekitar empat hingga enam tahun yang memiliki karakter yang berbeda dan masih dalam tahap pertumbuhan dan perekmbangan terutama dari segi mental, tentu ini unik dan menarik untuk diteliti lebih jauh, terutama peran kepala RA dalam mengembangkan pola kepemimpinan sekolah tersebut.

Pembelajaran anak usia dini sesungguhnya harus menekankan pada keterlibatan anak secara aktif, sehingga anak dapat memperoleh pengalaman langsung dan terlatih untuk menemukan sendiri berbagai pengetahuan yang dipelajarinya. Dengan diberikan pengalaman langsung (real experience), anak akan memahami konsep yang dipelajari dan menghubungkannya dengan konsep lain yang telah dipelajari.

Melihat tuntutan dan tantangan yang besar maka peran kepemimpinan sangat penting, sehingga sinergitas yang diharapkan oleh orang tua anak atau stakeholder dapat terwujud. Bahkan Nicolas Hans mengungkapkan "Ceritakan sekolahmu, maka akan dapat kuceritakan keadaan masyarakat dan Negaramu" (Irianto, 2011:2)

Fred E. Fiedler dan Martin M. Chamers dalam Wahjosumidjo dalam bukunya berjudul Leadership and effective Management dikemukakan bahwa persoalan utama kepemimpinan secara kasar dapat dibagi menjadi 3 pertanyaan pokok, yaitu: a) bagaimana seseorang dapat menjadi seorang pemimpin (how one become a leader); b) bagaimana para pemimpin itu berperilaku (how leader behave); c) apa yang membuat pemimpin itu berhasil (what makes the leader effective) (Wahjosumidjo. 2010: 9)

Dalam sebuah organisasi pendidikan tentu ada standar yang diberlakukan, sebagai landasan dalam pencapai kualitas pendidikan. Standar PAUD Peraturan Menteri Pendidikan Nasional Nomor 58 tahun 2009 terdiri atas empat kelompok, yaitu: (1) Standar tingkat pencapaian perkembangan; (2) Standar pendidik dan tenaga kependidikan; (3) Standar isi, proses, dan penilaian; dan (4) Standar sarana dan prasarana, pengelolaan, dan pembiayaan.

Kualitas Standar penyelenggaraan pendidikan saat ini diukur dari terakreditasinya sebuah lembaga pendidikan oleh BAN, melihat data Pendidikan saat ini adalah Pada Kantor Wilayah Kementerian Agama Provinsi Maluku, tercatat 52 Satuan Pendidikan RA tersebar di lima Kabupaten/Kota dengan rincian sebagai berikut: 1) Kota Ambon 11 RA ada 2 yang terakrediatas; 2) Kota Tual 2 RA ada 1 yang terakreditas; 3) Kabupaten Maluku Tengah 28 RA dan baru 1 RA yang terakreditasi; Kabupaten Buru 8 RA dan Seram 3 RA semuanya belum ada yang terakreditasi.

Dari data tersebut ada tiga Kabupaten/Kota yang memiliki jumlah populasi RA yang besar yaitu: Kabupaten Maluku Tengah, Kota Ambon dan Kabupaten Buru. beberapa data awal yang dapat dijadikan pertimbangan mengapa pentingnya peran Kepemimpinan karena perlu adanya pengelolaan yang lebih baik, terutama RA yang dikelola dibawah pengawasan Kementerian Agama. 
Problem kemudian adalah dengan kondisi guru yang sedikit, kemudian menghadapi karakter anak-anak yang berusia 4- 6 tahun tentu harus memerlukan kreatifitas serta inovasi dan kreatifitas, mulai dari sistem pembelajarannya, cara pelaksanaan kurikulum, pengembangan sarana dan prasarananya, dengan harapan agar guru dan anak-anaknya tidak mengalami kejenuhan dalam memberi dan mengikuti proses pembelajaran, demikian juga dengan kepemimpinan di RA yang dihubungkan dengan Peraturan Menteri Pendidikan Nasional Nomor 58 tahun 2009 tentang standar Pendidikan Anak Usia Dini

Berdasarkan latar belakang di atas penelitian ini mengangkat permasalahan bagaimana Kepala RA As-Salam Kota Ambon dalam meningkatkan kualitas pendidikan RA, dengan penjabaran Pertama Bagaimana model pengembangan Kepemimpinan RA dihubungkan dengan ketercapaian melaksanakan Peraturan Menteri Pendidikan Nasional Republik Indonesia Nomor 58 Tahun 2009 Tentang Standar Pendidikan Anak Usia Dini? Kedua Bagaimana model pengembangan kepemimpinan dihubungkan dengan variasi model pembelajaran?

Tujuan dari penelitian ini adalah Mengumpulkan data dan Informasi serta menganalisa tentang: Pertama Pelaksanaan Standar Pendidikan Anak Usia Dini sesuai Peraturan Menteri Pendidikan Nasional Republik Indonesia Nomor 58 Tahun 2009 dikaitkan dengan pengembangan model Kepemimpinan RA. Kedua model pembelajaran di RA As-Salam dikaitkan denga model Kepemimpinan.

Penelitian ini di Lakukan di Kota Ambon, tepatnya di Kecamatan Sirimau dimana RA yang dijadikan sampel adalah RA As-Salam. Penelitian ini merupakan penelitian Kualitatif. Data yang diperoleh dengan melakukan wawancara yang mendalam terhadap Kepala RA dan Guru RA.

\section{TINJAUAN PUSTAKA}

\section{Prinsip-Prinsip Perkembangan Anak Usia Dini}

Ada berbagai kajian tentang hakikat anak usia dini, khususnya anak TK diantaranya oleh Bredecam dan Copple, Brener, serta Kellough dalam Masitoh dkk., sebagai berikut. a) Anak bersifat unik; b) Anak mengekspresikan perilakunya secara relatif spontan; c) Anak bersifat aktif dan enerjik; d) Anak itu egosentris; e) Anak memiliki rasa ingin tahu yang kuat dan antusias terhadap banyak hal; f) Anak bersifat eksploratif dan beriwa petualang; g) Anak umumnya kaya dengan fantasi; h) Anak masih mudah frustrasi; i) Anak masih kurang pertimbangan dalam bertindak; j) Anak memiliki daya perhatian yang pendek; k) Masa anak merupakan masa belajar yang paling potensial; l) Anak semakin menunjukkan minat terhadap teman (Masitoh, 2005: 112-113)

Prinsip-prinsip perkembangan anak usia dini berbeda dengan prinsip-prinsip perkembangan fase kanak-kanak akhir dan seterusnya. Adapun prinsip-prinsip perkembangan anak usia dini menurut Bredekamp dan Coople dalam Siti Aisyah dkk. adalah sebagai berikut: 1) Perkembangan aspek fisik, sosial, emosional, dan kognitif anak 2) Perkembangan anak terjadi dalam suatu urutan tertentu yang relative dapat diramalkan; 3) Perkembangan dalam rentang bervariasi antar anak; 4) Pengalaman awal anak memiliki pengaruh kumulatif; 5) Perkembangan anak ke arah yang makin kompleks, terinternalisasi; 6) Cara belajar anak dipengaruhi oleh social budaya yang majemuk; 7) Anak adalah pembelajar aktif; 8) Belajar merupakan interaksi kematangan biologis dan lingkungan; 9) Bermain merupakan sarana penting bagi perkembangan anak; 10) Perkembangan akan mengalami percepatan bila anak berkesempatan untuk mempraktikkan berbagai keterampilan; 11) Anak memiliki modalitas beragam; 12) Kondisi terbaik anak untuk berkembang dan belajar adalam dalam komunitas yang menghargainya, memenuhi kebutuhan fisiknya, dan aman secara fisik dan fisiologis (Siti Aisyah dkk. .2007: 117-123)

Berdasarkan tinjauan secara psikologi dan ilmu pendidikan, masa usia dini merupakan masa peletak dasar atau fondasi awal bagi pertumbuhan dan perkembangan anak. Apa yang diterima anak pada masa usia dini, apakah itu makanan, minuman, serta stimulasi dari lingkungannya memberikan kontribusi yang sangat besar pada pertumbuhan dan perkembangan anak pada masa itu dan berpengaruh besar pertumbuhan serta perkembangan selanjutnya.

Secara umum tujuan pendidikan anak usia dini adalah mengembangkan berbagai potensi anak sejak dini sebagai persiapan untuk hidup dan dapat menyesuaikan diri dengan lingkungannya. Secara khusus tujuan pendidikan anak usia dini sebagaimana yang diungkapkan Yuliani adalah: 1). Agar anak percaya akan adanya Tuhan dan mampu beribadah serta mencintai sesamanya; 2) Agar anak mampu mengelola keterampilan tubuhnya termasuk gerakan motorik kasar dan motorik 
halus, serta mampu menerima rangsangan sensorik; 3) Anak mampu menggunakan bahasa untuk pemahaman bahasa pasif dan dapat berkomunikasi secara efektif sehingga dapat bermanfaat untuk berpikir dan belajar; 4) Anak mampu berpikir logis, kritis, memberikan alasan, memecahkan masalah dan menemukan hubungan sebab akibat; 5) Anak mampu mengenal lingkungan alam, lingkungan social, peranan masyarakat dan menghargai keragaman social dan budaya serta mampu mngembangkan konsep diri yang positif dan control diri; 6) Anak memiliki kepekaan terhadap irama, nada, berbagai bunyi, serta menghargai karya kreatif (Yuliani. 2009: 42-43)

\section{Teori dan Model Kepemimpinan}

Pemimpin mempunyai tanggung jawab baik secara fisik maupun moralitas terhadap keberhasilan aktivitas kerja dari yang dipimpin, sehingga menjadi pemimpin itu tidak mudah dan tidak akan setiap orang mempunyai kesamaan di dalam menjalankan kepemimpinannya

Teori dasar munculnya kepemimpinan menurut Siagian (2004: 9-10), Anoraga (2003: 3), Kartono (2010: 33-34) Munculnya pemimpin secara garis besar tiga teori yang menonjol, pertama Teori Genetis (Pemimpin itu tidak dibuat tetapi lahir jadi pemimpin, secara filosofis teori ini menganut pandangan deterministis), Kedua Teori Sosial, ini merupakan lawan dari teori genetis yang menyatakan bahwa pemimpin itu harus disiapkan, dididik, dan dibentuk tidak lahir begitu saja, Ketiga Teori Ekologis (sintesis) muncul sebagai reaksi dari kedua teori sebelumnya, yang artinya pemimpin bila memiliki bakat sebagai pemimpin dan dikembangkan melalui pengalaman.

Bahkan lebih lanjut menurut Kartono (2010: 71) Banyak studi ilmiah dilakukan orang mengenai kepemimpinan, dan hasilnya berupa teori-teori tentang kepemimpinan. Teori-teori yang muncul menunjukkan perbedaan dalam: a) pendapat dan uraiannya; 2) Metodologinya; 3) interpretasi yang diberikan; 4) kesimpulan yang ditarik.

Kadarusman (2012: 214) Ciri seorang pemimpin kelompok (team leader) yang memiliki kecerdasan hakiki yang tinggi tercermin dalam kemampuannya untuk memahami apa yang menjadi tanggungjawab kepemimpinannya, menyelami kondisi bawahannya, kesediaan untuk meleburkan diri dengan tuntutan dan konsekuensi dari tanggungjawab yang dipikulnya, serta komitmennya untuk membawa setiap bawahan yang dipimpinnya mengeksplorasi kapasitas dirinya sehingga menghasilkan prestasi tertinggi.

Jenis-jenis teori kepemimpinan sangat variatif dikemukakan dalam berbagai literatur, misalnya yang dikemukakan Salusu (2006: 198201), membagi teori kepemimpinan menjadi 8 (delapan) jenis yaitu: (1) Teori-teori besar (Great-Man Theories) Teori ini dipopulerkan pada 1840-an oleh penulis Skotlandia Thomas Carlyle, dan pada tahun 1860 Herbert Spencer merumuskan argumennya sehingga tetap berpengaruh sepanjang abad ke-20 sampai sekarang; (2) Teori Sifat (Traith Theories); (3) Teori Lingkungan (Environmental Theories); (4) TeoriSituasional pribadi (PersonalSituasional Theories); (5) Teori Psikoanalitik (Psycoanalityc Theories); (6) Teori AntisipasiInteraksi (Interaction-Expectation Theories); (7) Teori manusia (Humanistic Theories); (8) Teori Pertukaran (Exchange Theories).

\section{Kelompok Kepemimpinan Klasik \\ Kepemimpinan Model Taylor (1911)}

Mengenai kepemimpinan menurut teori perilaku, ada tiga hasil penelitian yang menoncol yakni pertama Studi kepemimpinan Iowa yang diteliti oleh Ronald Lippitt dan Ralp K. White, kemudian yang kedua di Ohio State University dan penelitian yang dilakukan di University of Michigan. Para peneliti tentang kepemimpinan tinjauan perilaku lebih saat ini banyak memberikan apresiasi kepada penelitian yang dilakukan di Ohio dan Michigan.

Publikasi karya Frederick Winslow Taylor pada tahun 1911 yang berjudul: Principle of Scientific Management, mencirikan permulaan konstruksi teori secara serius bidang manajemen dan organisasi-organisasi. (Winardi, 2002: 124).

\section{Kepemimpinan Model Mayo (1920)}

Kepemimpinan model Mayo sangat terkenal dengan gerakan hubungan manusia yang merupakan reaksi dan revisi kepemimpinan ala Taylor yang memperlakukan manusia sebagai mesin. (Pasolong, 2010: 87).

\section{Studi Iowa (1930).}

Penelitian ini dilakukan oleh Lippit dan White dari Universitas Iowa, pada tahun 1930 yang menaliti anak yang berumur 10 tahun dengan memainkan peran kepemimpinan Otoriter, demokratis dan Laize Faire. (Pasolong, 2010: 87). 


\section{Studi Kepemimpinan Universitas Ohio}

Di antara beberapa program besar penelitian kepemimpinan yang terbentuk setelah perang Dunia II, satu yang paling signifikan adalah penelitian yang dipimpin oleh Fleishman dan rekan-rekannya di Bureau of Bussines Research di Ohio State university. Program ini menghasilan perkembangan teori dua faktor dari kepemimpinan, yaitu membentuk struktur dan konsiderasi (Rivai, 2012: 9)

Sebagaimana Bass (1990), Kerrdan Schrieshein (1974). Yukl (1971) dalam Pasolong (2010: 83) pada beberapa studi para bawahan lebih puas dan bekerja lebih baik dari seorang pemimpin yang structuring, sedangkan studi lainnya hubungan yang kebalikan atau hubungan yang nyata tidak ditemukan. Penemuan tersebut juga tidak konsisten mengenai hubungan concideration dan kriteria kinerja. Satusatunya hubungan yang cukup konsisten adalah efek concideration terhadap kriteria kepuasan.

\section{Studi Kepemimpinan Michigan}

Fokus penelitian Michigan adalah identifikasi hubungan diantara perilaku pemimpin, proses kelompok dan ukuran mengenai kinerja kelompok (Yukl, 2009: 65)

Para peneliti dari Michigan mengamati tindakan-tindakan pengawas dan kemudian melakukan survei terhadap para bawahannya. Para peneliti berkesimpulan bahwa mereka dapat mengukur perilkau para pengawas dengan dimensi tunggal. Dimana ujung yang satu dinamakan "terpusat pada Pekerja" (Employee centered) sementara ujung yang lainnya dinamakan "terpusat pada tugas" (task centered). (Sashkin, 2011: 20)

Riset di University of Michigan mengidentifikasi dua jenis perilaku kepemimpinan. Pertama, orientasi pekerja yaitu perilaku pemimpin yang mendekati bawahan dengan penekanan hubungan manusia yang kuat. Mereka menaruh perhatian pada pekerja sebagai makhluk hidup, menghargai individualitas mereka, dan memberi perhatian khusus atas kebutuhan pribadi mereka. Kedua, orientasi produksi, terdiri atas perilaku pemimpin yang menekankan pada aspek teknis dan produksi dari suatu pekerjaan. Dari orientasi ini, pekerja dilihat sebagai alat guna menyelesaikan pekerjaan.

\section{Kelompok Kepemimpinan Modern Teori Sifat}

Teori sifat kepemimpinan juga disebut Traith Theory. Teori sifat ini beracu terhadap pandangan sifat-sifat, watak-watak dan karakter yang dimilik oleh seorang individu. Rivai (2012: 7) Teori ini berusaha untuk mengidentifikasi karakterisitik khas (fisik, mental, kepribadian). Yang dikaitkan dengan keberhasilan kepemimpinan. Teori kepemimpinan ini menyatakan bahwa keberhasilan manajerial disebabkan karena kemampuan-kemampuan luar biasa seorang pemimpin.

Makawimbang (2012: 12) Kemampuan pribadi yang dimaksud adalah kualitas seseorang dengan berbagai sifat, perangai atau ciri-ciri didalamnya. Wahyudi (2009: 123) Pendekatan berdasarkan sifat mengkaji tentang perangai dan kemampuan yang menandai karakteristik pemimpin yang berhasil dan tidak berhasil. Wahjosumidjo (2010: 22) Pendekatan sifat (The Trait Approach) selain sifatsifat pribadi, juga ditentukan pula oleh kecakapan/ keterapilan (skill) pribadi pemimpin.

\section{Teori Situasional atau Kontingensi}

Teori Kontijensi dalam kajian kepemimpinan fokus pada interaksi antara variabel-variabel yang terlibat di dalam situasi serta pola-pola perilaku kepemimpinan. Teori Kontijensi didasarkan atas keyakinan bahwa tidak ada satupun gaya kepemimpinan yang cocok bagi aneka situasi.

Beberapa pengembangan Model Teori Kontijensi terdiri atas, pertama Model Kontijensi LPC dari Fred Edward Fiedler (1964) menjelaskan bagaimana situasi menengahi hubungan antara efektivitas kepemimpinan dengan ukuran ciri yang disebut "Nilai (LPC) rekan kerja yang paling tidak disukai (Yukl, 2009: 252). Kedua Model Kontijensi dari Victor Harold Vroom and Philip W. Yetton (1973) adalah kebutuhan akan kepemimpinan yang lebih partisipatif saat terdapat sebuah tugas yang rumit dan tidak terstruktur dan bawahan (atau anggota tim) memiliki pengetahuan yang relevan dan ide kreatif mengenai bagaimana melakukan tugas itu (Yukl, 2010: 279)

\section{Teori Jalan Kecil Tujuan (Path-Goal Theory) (1974)}

Menurut teoripath-goal, suatu perilaku pemimpin dapat diterima oleh bawahan pada tingkatan yang ditinjau oleh mereka sebagai sebuah sumber kepuasan saat itu atau masa mendatang. Perilaku pemimpin akan memberikan motivasi sepanjang (1) membuat bawahan merasa butuh kepuasan dalam pencapaian kinerja yang efektif, dan (2) menyediakan ajaran, arahan, dukungan dan 
penghargaan yang diperlukan dalam kinerja efektif (Robins, 2003: 74).

\section{Teori Perilaku (Behavior Theory)}

Teori perilaku (Behavior Theory) dilandasi pemikiran, bahwa kepemimpinan merupakan interaksi antara pemimpin dan pengikut, dan dalam interaksi pengikutlah yang menganalisis dan mempersepsi apakah mau menerima atau menolak pengaruh dari pemimpinya (Pasolong, 2010: 91)

Menurut Yukl (2009: 75) sebuah masalah besar dalam penelitian mengenai kandungan dari perilaku kepemimpinan adalah identifikasi kategori perilaku yang relevan dan berarti bagi semua pemimpin. Taksonomi yang berbeda telah timbul dari disiplin penelitian yang berbeda, dan sulit sekali untuk menterjemahkan sejumlah konsep ke konsep lainnya, Beberapa taksonomi perilaku yang diusulkan selama 50 tahun terakhir.

\section{PEMBAHASAN}

\section{Gambaran Umum RA As-Salam}

RA Assalam yang telah memperoleh Akreditasi dari BAN ini terletak di Kebun Cengkeh, Batu merah kecamatan Sirimau, dipimpin oleh Dani Yuliati Amba, S.Pi (seorang sarjana Perikanan) sebagai Kepala RA dan dibantu oleh delapan orang guru perempuan, saat ini mengasuh anak-anak berjumlah 103 orang yang terdiri dari 58 orang pria dan 45 perempuan.

Dalam penelitian ini penulis akan lebih melihat bagaimana seorang Kepala RA (Dani Yuliati Amba) sebagai pimpinan yang bukan memiliki latar belakang pendidikan dapat melakukan inovasi dalam pengelolaan RA As-Salam Kota Ambon sehingga sekolah RA tersebut dapat memberikan nilai tambah dan disebut sebagai RA yang berkualitas.

Jika ditinjau dari segi Visi RA Assalam mencanangkan "menjadi RA yang terkemuka dalam membangun generasi yang berkarakter, cerdas, kreatif dan berakhlak yang baik (akhlakul kharimah).

Misi yang ingin dicapai oleh RA As-Salam yakni: 1) Mengembangkan model pendidikan karakter dengan metode efektif untuk anak usia dini; 2) Menghasilkan generasi yang memiliki keimanan dan ketakwaan serta menimbulkan sikap toleran antar sesama; 3) melakukan metode pembelajaran yang menyenangkan, kekinian dan dekat dengan lingkungan.

Tujuan pendirian RA Assalam Ambon sebagai berikut: 1) memberikan kemampuan dasar kepada peserta didik berupa pengetahuan dan keterampilan serta sikap yang merupakan penunjang untuk melanjutkan pendidikan kejenjang berikutnya; 2) mengintegrasikan kemampuan, keterampilan dan sikap yang islami kepda peserta didik; 3) membentuk peserta didik menjadi manusia yang mempunyai kepribadian.

Struktur Kurikulum RA Assalam tingkat pencapaian perkembangan yang ingin dicapai dalam bidang 1) Pengembangan Nilai Agama Islam dan Moral; 2) Fisik/Motorik; 3) Kognitif; 4) Bahasa; 5) Sosial dan; 6) Muatan lokal adalam Qiraati Ummi dengan mengoptimalkan 5 hari dalam sepekan dan total waktu setiap kali pertemuan 240 menit.

Pencapaian perkembangan anak dan kriteria penilaian, pada prinsipnya tingkat pencapaian perkembangan anak dikatakan berhasil jika anak telah mencapai nilai yang telah diprogramkan dengan ketentuan nilai yang berupa narasi yang dicatatan pada format nilai, yang digambarkan sebagai berikut: 1) Kode $1 / \mathrm{O}=$ digambarkan bahwa anak tidak mau dan belum mampu melakukan kegiatan; 2) Kode $2 / \mathrm{O}=$ Anak sudah mampu namun masih dibimbing; 3) Kode $3 / O=$ Anak sudah mampu tanpa bimbingan dengan hasil yang bagus; 4) Kode $4 / \mathrm{O}=$ Anak sudah mampu mengerjakan tugas dengan hasil melebihi dari program guru.

Program pembelajaran di RA. adalah proses interaksi peserta didik dengan pendidik atau sumber belajar pada suatu lingkungan belajar. Program itu berfungsi untuk membina, menumbuhkan, mengembangkan seluruh potensi anak secara optimal sehingga terbentuk prilaku dan kemampuan dasar sesuai dengan tahap perkembangan anak agar memiliki kesiapan untuk memasuki pendidikan selanjutnya.

Sebagaimana yang ditetapkan oleh Direktorat Pendidikan Madrasah kemenag, Program ini bertujuan untuk pertama, Membangun landasan bagi berkembangannya potensi peserta didik agar menjadi manusia beriman dan bertaqwa kepada Tuhan Yang Maha Esa, berakhlak mulia, berkepribadian luhur, sehat, berilmu, cakap, kritis, kreatif, inovatif, mandiri, percaya diri dan menjadi warga negara yang demokratis dan bertanggung jawab, Kedua Mengembangkan potensi kecerdasan spiritual, intelektual, emosional, kinestetis dan sosial peserta didik pada masa usia emas pertumbuhan dalam lingkungan bermain yang edukatif dan menyenangkan. Ketiga Membangun peserta didik mengembangkan berbagai potensi baik psikis dan fisik yang meliputi akhlakul karimah, sosioemosional dan kemandirian, pendidikan agama 
Islam (PAI), bahasa, kognitif dan fisik/motorik, untuk siap memasuki pendidikan dasar.

Kerangka dasar pembelajaran di RA. didasarkan pada PP Nomor 17 Tahun 2010 tentang pengelolaan dan penyelenggaraan pendidikan, program pembelajaran RA/TK dan bentuk lain yang sederajat dilaksanakan dalam konteks bermain sambil belajar yang dikelompokkan menjadi bermain dalam rangka pembelajaran: a) akhlak mulia; b) sosial dan kepribadian; c) orientasi dan pengenalan pengetahuan dan teknologi; d) estetika dan e) jasmani, olahraga dan kesehatan.

\section{Kepemimpinan dan kreatifitas pengelolaan media informasi}

Pengelolaan sekolah yang dipimpin ibu Dani juga memanfaatkan kreatifitas dalam pemanfatan media-media informasi misalkan di dalam kelas terdapat sejumlah informasi yang memiliki nuansa keagamaan, diantaranya terdapat sebuah tulisan kawasan orang memakai jilbab, ini memberikan pelajaran tentang pentingnya ber-hijab sejak dini ditanamkan pada anak-anak RA As-salam.

Kreatifitas lainnya pada kelas-kalas pimpinan memberikan nama dengan nama yang memiliki arti yang positif untuk tumbuh kembang anak misalnya:

Pada kelas A, yakni kelompok usia 3-4 tahun dan diberi nama kelas "mandiri" dengan harapan bahwa anak-anak kelak sifat kemandirian dapat dipupuk agara siswa menjadi orang yang sadar akan kemampuannya dan ini juga berpengaruh pada karakter mereka.

Kelas B1 (Kelompok usia 5-6 tahun) diberi nama kelas "rendah hati" terselip sebuah harapan bahwa anak-anak tidak boleh memiliki sifat sombong, ketika anak-anak berada dalam ruang belajar ini, kesadaran akan rendah diri ini dapat terbangun tanpa disadari oleh anak-anak. Dan meminimalisir secara berlahan anak-anak yang memiliki sifat ego dan suka membanggakan diri.

Pada Kelas B2 (Kelompok usia 5-6 Tahun) diberi nama kelas "Amanah". Sifat ini adalah salah satu sifat Nabi Muhammad SAW, yakni jika diberikan tanggungjawab maka haruslah mereka "amanah" terhadap tanggungjawab tersebut.

Pada ruangan di kelas B3 (Kelompok usia 5-6 Tahun) diberi nama kelas "Disiplin" agar anak-anak terbiasa melakukan sesuatu secara teratur dan tepat waktu, sifat ini perlu

Sementara untuk kegiatan di dalam kelas, terdapat sejumlah tulisan seperti huruf-huruf hijaiyah, marhaban, ramadhan, puasa, shalat, sahur, ibadah, sedekah dan miniature rumah ibadah. Selain itu juga terpajang gambar tata cara orang mengambil wudhu dan shalat, walaupun terlihat gambar dan medianya sederhana tapi kesannya sudah komunikatif bagi anak-anak pada usia dini.

\section{Kepemimpinan dan Kreatifitas penerapan kedisiplinan}

Dalam menerapak kedisiplinan, pimpinan RA As-Salam melakukan hal yang juga mungkin secara umum dilakukan di RA lainnya, mislakan sebelum anak-anak masuk kelas terlebih dahulu mereka berbaris dengan tertib sebagai salah satu upaya penanaman kedisiplinan. Khusus kegiatan nilainilai keagamaan yang ditanamkan yang dilakukan antara lain:Yel-yel anak karakter dengan bertepuk tangan tiga-tiga kali sambil mengucapkan Allah, Muhammad dan kata-kata yang mengandung makna zikir, yang lainnya menyanyikan lagu yang bernuansa islami, sebelum memasuki kelas setiap anak-anak berjabat tangan dan mencium tangan ibu guru, ini juga untuk menanamkan karakter bagi anak sejak dini.

\section{Kepemimpinan dan Kreatifitas pengembangan Kurikulum}

Pengembangan kurikulum bagi sekolah merupakan suatu tantangan, karena ini bersifat universal, maka dibutuhkan kreatifitas pimpinan untuk mengolahnya lebi aplikatif dan disesuaikan dengan lingkungan pendidikan RA As-Salam.

Kurikulum RA dalam pengertiannya adalah seperangkat rencana dan pengaturan mengenai tujuan bidang pengembangan serta cara yang digunakan sebagai pedoman penyelenggaraan kegiatan pembelajaran untuk mencapai tujuan pendidikan. Diantara tujuan yang dirumuskan dalam kurikulum RA As-salam adalah pertama mengintegrasikan kemampuan, keterampilan dan sikap yang islami kepda peserta didik, kedua membentuk peserta didik menjadi manusia yang mempunyai kepribadian.

Kurikulum RA As-Salam, menurut Dani Yulianti Amba, S.Pi penyusunannya melibatkan Kepala RA, guru, komite RA, pengurus yayasan Assalam, pengawas RA dan tim pengembang kurikulum. Kini, kurikulum yang digunakan adalah kurikulum sendiri yang dikonstruksi dari perpaduan kurikulum kemendikbud, kemenag dan kurikulum sekolah Islam terpadu yang dikembangkan oleh Indonesia Heritage Foundation (IHF). (wawancara tanggal 28 September 2012 di Ambon) 
Pengembangan kurikulum RA As-Salam mencakup Bidang, meliputi, Pengembangan nilai Agama Islam dan moral, Fisik/motoric, Kognitif, Bahasa dan social sedangan untuk Muatan Lokal, Berupa baca tulis Al- Qur'an dengan menggunakan buku Ummiyang di terbitkan oleh sekolah Islam terpadu.

Berkaitan dengan bidang, disajikan secara tematik. Pembelajaran dilakukan secara holistic pilar yang jumlahnya 10 pilar. Setiap pilar memuat tiga karakter. Masing-masing pilar berbeda tema karakternya antara satu dengan lainnya. Berdasarkan dokumen pada RA Assalam, kesepuluh pilar dimaksud adalah sebagai berikut.a) Pilar 1 (Ta’zim dan Setia); b) Pilar 2 (Mandiri, Displin, Tanggungjawab); c) Pilar 4 (Pendengar yang baik, hormat, patuh, sopan dan santun); d) Pilar 5 (Suka menolong, dermawan dan kerjasama); e) Pilar 6 (Percaya diri, kreatif dan kerja keras); f) Pilar 7 (Kepemimpinan, keadilan); g) Pilar 8 (Baik hati dan Rendah Hati); h) Pilar 9 (Toleransi, kedamian, kesatuan); i) Pilar 10 (Kebersihan, kerapian, kesehatan dan keamanan).

Dari kesepuluh pilar tersebut, penulis melihat adanya kreatifitas dalam pemberian nama dan materi yang diberikan pada masing-masing pilar tersebut, tentu hal ini didasari oleh inovasi dan kreatifitas dari pimpinan dalam pemberian nama, sehingga terlihat menarik dan memberikan nilai yang lebih bermakna.

Pilar-pilar karakter pada satu sisi disandarkan pada lingkup perkembangan dan pertumbuhan anak untuk mendukung kontinuitasnya. Pada sisi lain, pilar karakter dikembangkan kedalam tema ataupun konsep seperti yang dituangkan dalam Buku Pilar, mencapai sampai 28 item setiap buku. Masing-masing tema ataupun konsep dapat dikembangkan menjadi sub-sub tema atau konsep yang dituangkan dalam SKH (Satuan Kegiatan Harian). Sub-sub tema pengembangannya menjadi kreatifitas guru dalam menentukannya.

Untuk membantu guru merumuskan sub-sub tema, dapat dibangun melalui pertemuan guru yang dilakukan setiap hari Sabtu, atau melalui referensi yang dimiliki oleh RA As-salam. Saat penelitian dilakukan, buku referensi dimaksud tercatat 120 buah, diluar buku pilar. Pilar karakter, tema dan sub tema dengan sumbernya dituangkan dalam SKH sebagai jadwal kegiatan pembelajaran setiap hari. SKH dibuat/disiapkan setiap minggu oleh guru. Strukturnya meliputi a) Penentuan pilar konsep dan temanya; b) Menyusun implementasinya kedalam waktu, indikator, kegiatan, tahapan kegiatan dan media.

Aspek yang tersusun dalam kegiatan, selain berbaris juga morning circle, yakni kegiatan pembelajaran awal. Nilai keagamaan yang diterapkan, membaca surah AnNas, doa masuk dan keluar kamar mandi, doa bercermin, hadis-hadis kebersihan dsb, kreatifitas yang ingin ditanamkan pada kegiatan pagi yang diistilahkan dengan morning circle agar daya serap dan daya ingat anak terus terbangun.

Pilar karakter mengacu pada konsep "tanggung jawab" dikembangkan kedalam tematema tanggung jawab pada Allah, diri sendiri, orang lain dan alam. Nilai keagamaan yang ditanamkan pada anak bila dilakukan dengan baik dan ikhlas, bernilai ibadah.

Kemudian didalam SKH ada jadwal dan istirahat. Saat makan diajak membaca doa, membaca basmalah dan memulai dengan tangan kanan.

Struktur SKH selanjutnya adalah kegiatan "sentra" hal ini semacam ruangan-ruangan yang terpisah menjadi empat bagian yang diistilahkan dengan "sentra". Kegiatan ini adalah tindak lanjut dari pembelajaran pilar yang telah dilakukan, kegiatannya dalam bentuk praktek

Setiap siswa dalam satu minggu akan memasuki "sentra" tersebut secara bergiliran

Ada 4 Sentra di RA. Assalam, yaitu: 1) Sentra Rancang bangun dan persiapan; 2) Sentra Explorasi dan seni; 3) Sentra ibadah dan 4) Sentra cooking

Saat penelitian, kegiatan di sentra rancang dan bangun pandu oleh Ibu Rugaya dan Setna, dengan mengajak anak-anak memerankan sebuah keluarga besar yang dilambangkan dengan pohon keluarga besar. Beberapa anak mengambil peran dalam keluarga itu. Masing-masing pemeran disimbolkan dengan gambar, lalu anak menampilkannya sesuai ruang dibagan dipohon keluarga besar: Nilai agama-agama yang ditanamkan adalah saling menghormati dan menyayangi diantara sesama keluarga. (wawancara dan observasi, 01 September 2012).

Di Sentra ibadah, dipandu oleh Ibu Sia guru kelas B3. Tema kegiatan adalah "Anak yang berbakti pada orangtua". Untuk menunjukkan perlakuan yang baik pada orang tua, diputarkanlah film anak-anak, yang memuat nyanyian yang islami, bangun pagi, shalat, doa terhadap orangtua, anak shaleh, pentingnya membaca Al Qur'an, ada pesan akhlak dilarang mengejek dan saling memaafkan. (wawancara dan observasi, 02 September 2012). 
Di Sentra cooking, dipandu oleh Ibu Leha, guru kelas A, mengajak anak memasak. Diperkenalkanlah makanan halal dan bergizi, juga dikaitkan dengan kekuasaan Allah yang menciptakan bahan makanan untuk manusia. (wawancara dan observasi, 28 September 2012).

\section{Kepemimpinan dan Kreatifitas kegiatan Ekstra kurikuler}

Saat dilapangan ada juga yang menarik dari pola pengelolaan sehingga anak-anak merasakan nuansa lain selain kegiatan rutinitas di kelas yang diprogramkan dalam bentuk kegiatan ekstra kurikuler, diantaranya yang berdimensi agama yang dilakukan diantaranya:

Pelatihan manasik haji, kegiatan ini dilakukan minimal satu kali dalam satu tahun dengan mendemonstrasikan bersama tatacara pelaksanaannya, bahkan setiap anak diwajibkan menggunakan pakaian ihram layaknya orang melakukan ibadah Haji di Tanah suci makkah. Ini juga memberikan pembelajaran pada anak tentang salah satu rukun Islam yakni menunaikan Ibadah haji.

Untuk memperkenalkan akan ciptaan Allah SWT dengan cara melihat langsung sambil melakukan wisata alam, diantaranya kepantai liang (kawasan rekreasi di Kota Ambon). Disana diperkenalkan pada anak tentang kebesaran Allah melalui ciptaan-Nya dengan suasana alam yang indah.

Yang menarik juga adalah saat Hari Raya Idul Adha, sekolah tersebut melakukan kegiatan Qurban, saat itu para anak RA As-Salam di ajak untuk menyaksikan pemotongan hewan qurban. Dalam suasana itu, dijelaskan tentang sejarah qurban dan pengabdian dan kepatuhan seorang anak saleh bernama Ismail.

\section{Kepemimpinan dan kreatifitas evaluasi Pembelajaran}

Evaluasi menurut permendiknas nomor 58 tahun 2009 tentang standar pendidikan anak usia dini (PAUD), adalah proses pengumpulan da pengolahan informasi untuk menentukan tingkat pencapaian perkembangan anak. Bahasannya meliputi: tekhnik penilaian, lingkup penilaian, proses penilaian, pengolahan hasil, dan tindak lanjut hasil penilaian. Tahapan pelaksanaan evaluasi dapat dilakukan secara harian, mingguan, bulanan, tengah semester, semester, dan ujian akhir

Evaluasi harian, terkait penyerapan anak terhadap materi pelajaran yang diberikan pada hari itu dan juga kepatutan anak dalam menerimanya. Di sini berlaku reward dan panishment. Hasil evaluasi dalam bentuk reward, diberikan kepada anak yang memiliki kepatutan dalam pembelajaran berupa penyematan bintang di baju pada dada bagian kanan. Hasil evaluasi dalam bentuk panishment di berikan kepada anak yang menunjukkan tingkat kepatutan rendah berupa time out yakni menyuruh anak berdiri di sudut kiri bagian depan ruang kelas selama jam tahapan pelajaran bersangkutan berlangsung.

Evaluasi mingguan, dilakukan oleh guru dengan memerhatikan perkembangan anak dalam menyerap materi pelajaran berdasarkan tema-tema bahasa dan tingkat kepatutannya. Hal itu dilakukan oleh guru setiap akhir pekan pembelajaran yakni pada hari sabtu, karena mereka menerapkan hari sekolah hanya lima hari dalam seminggu. Dalam pertemuan itu para guru berbagi pengalaman dalam pengamatan tentang kemajuan perkembangan dan daya serap anak serta kendala yang dihadapi mereka. Kemudian mencari solusi mecehannya dengan merumuskan secara bersama-sama.

Selain itu, ada pula evaluasi yang dilakukan orang tua siswa terhadap anaknya di rumah. Orang tua mencatatkan pada lembaran yang dikirimkan oaleh RA kepadanya berisikan sejumlah item dalam benntuk matrik yang lebih menekankan pada perkembangan karakter anak. Penilaiannya disesuaikan dengan aspek dari tema karakter yang telah diajarka di RA. Tujuannya adalah untuk mengetahui tingkat implementasi karakter itu oleh anak di rumah dan lingkungannya. Hal ini adalah merupakan bagian dari perwujudan sinergitas pembelajaran yang di bangun antara guru di RA dengan orang tua di rumah.

\section{PENUTUP}

Berdasarkan hasil penelitian yang diperoleh melalui wawancara mendalam, observasi, dan study dokumentasi yang dilakukan, Kepala RA mengkombinasikan beberapa model gaya kepemimpinan yang sering diterapkan pada lembaga-lembaga pendidikan yang maju, ada beberapa aspek yang menjadi penunjang penanaman nilai-nilai agama pada RA As-salam, melalui kreatifitas kepemimpinannya maka dapat disimpulkan bahwa kreatifitas kepemimpinan kepala RA jika dihubungkan dengan pengelolaan media, sangat penting, karena hal ini menyangkut dangan sistem informasi, walaupun media-media yang dibuat sederhana, tapi mengandung makna, 
makin banyak anak-anak melihat gambar-gambar yang inspiratif, maka motivasi dan semangat untuk belajar juga akan terbangun.

Kreatifitas kepemimpinan kepala RA yang dikaitkan dengan kedisiplinan akan memberikan dampak yang baik, karena perilaku disiplin jika dibangun dalam kerangka yang tidak kreatif maka akan berpengaruh pada pola kejenuhan anak. Kreatifitas kepemimpinan kepala RA dalam mengembangkan kurikulum perlu dibangun secara bijak, karena kurikulum ini berlaku dalam jangka waktu yang panjang. Peran kepala RA sangat penting dalam memainkan peran mengolah kurikulum ini menjadi lebih menarik. Kurikulum yang dikembangkan dengan memadukan kurikulum Kemenag, Kemenndigbud, dan kurikulum sekolah Islam terpadu di kemas dalam pembelajaran holistik integratif antara pendidikan karakter, nilai-nilai Islami, dan pengembangan potensi fisik dan psikis anak.

Kreatifitas kepala RA dalam mengembangkan kegiatan ekstra kurikuler memberikan nilai positif, karena anak-anak diajak untuk melihat sacara nyata apa yang menjadi tujuan dari pembelajaran bagi anak usia dini. Kreatifitas kepala RA dalam mengembangkan sistem evaluasi menjadi bagian penting, hal ini perlu dipertimbangkan pada dampak psikologis anak, ketika evaluasi ini bersifat mempengaruhi perkembangan anak.

\section{UCAPAN TERIMA KASIH}

Ucapan terima kasih kepada Balai Litbang Agama Makassar yang telah memberikan kesempatan untuk melakukan penelitian di Kota Ambon, lebih ACLS Peneliti juga mengucapkan terima kasih kepada pengurus yayasan pendidikan As-Salam terutama Ibu Dany, SP. Sebagai Kepala RA As-Salam yang telah membantu Peneliti baik secara administrasi dan operasional pengajaran di kelas B sehingga memudahkan untuk menganalisa hasil data yang dihimpun. Para ibu guru RA AsSalam yang telah memberikan kesempatan untuk mengamati proses penelaahan pembelajaran di kelas B bagi anak-anak, Peneliti berharap apa yang telah dilakukan untuk meningkatkan kesadaran dan parvalue pershare-agama dapat terus dikembangkan, semoga tulisan ini dapat memberikan pencerahan buat pembaca.

\section{DAFTAR PUSTAKA}

Aisyah, Siti dkk. .2007. Perkembangan dan Konsep Dasar Pengembangan Anak Usia Dini.
Jakarta: Universitas Terbuka.

Anoraga, Pandji. 2003. Psikologi Kepemimpinan. Jakarta: Rineka Cipta.

Danim, Sudarman. 2010. Kepemimpinan Pendidikan Kepemimpinan Jenius (IQ+EQ) Etika, Perilaku Motivasional dan Mitos. Bandung: Alfabet.

Hesselbein, Frances. 2007. Change: How To be a Leader for the Future. Yogjakarta: Pustaka Pelajar.

Irianto, Yoyon Bahtiar. 2011. Kebijakan Pembaruan Pendidikan: Konsep, Teori dan Model. Jakarta: Rajagrafindo Persada.

Kadarusman, Dadang. 2012. Natural Intellegence Leadership, Cara Pandang Baru terhadap Kecerdasan dan Karakter Kepemimpinan, Jakarta: Raih Asa Sukses.

Kartono, Kartini. 2010. Pemimpin dan kepemimpinan (Apakah Kepemimpinan Abnormal Itu?). Jakarta: Rajagrafindo Persada.

Luthans, Fred. 2006. Perilaku Organisasi edisi 10. Yogjakarta: Andi.

Makawimbang, Jerry. H. 2012. Kepemimpinan Pendidikan yang Bermutu. Bandung: Alfabeta.

Masitoh dkk. 2005. Strategi Pembelajaran TK. Jakarta: 2005.

Pasolong, Harbani. 2010. Kepemimpinan Birokrasi. Bandung: Alfabeta.

Rivai, Veithzal \& Deddy Mulyana. 2012. Kepemimpinan dan Perilaku Organisasi, Jakarta: Rajagrafindo Persada.

Salusu, J. 2006. Pengambilan Keputusan Stratejik untuk Organisasi Publik dan Organisasi Non Profit. Jakarta: Grasindo.

Sashkin, Marshall \& Molly G. Marshall. 2012. PrinsipPrinsip Manajemen. Jakarta: Erlangga.

Siagian, Sondang. 2003. Teori dan Praktek Kepemimpinan, Jakarta: Rineka Cipta.

Wahjosumidjo. 2010, Kepemimpinan Kepala Sekolah (Tinjauan Teoritik dan Permasalahannya). Jakarta: Rajagrafindo persada.

Wahyudi. 2009. Kepemimpinan Kepala Sekolah dalam Organisasi Pembelajaran (Learning Organization). Bandung: Alfabeta.

White, Randall P. et.al. 1997. The Future of Leadership. Batam: Interaksara.

Winardi, 2002. Sejarah Perkembangan pemikiran alam Bidang Manajemen. Bandung: Mandar Maju.

Yukl. Gary. 2009. Leadership in Organization, Sith Edition (Delhi: Dorling Kinderstey)

Yuliani Nurani, Sujiono,. 2009. Konsep Dasar Pendidikan Anak Usia Dini. Jakarta: PT Indeks. 